\title{
The role of Treg cell subsets in allergic disease
}

\author{
Tadech Boonpiyathad, ${ }^{1,2}$ Zeynep Celebi Sözener, ${ }^{1,4}$ Mübeccel Akdis, ${ }^{1}$ Cezmi A. Akdis ${ }^{1,3}$
}

\begin{abstract}
Allergic diseases are caused by a hypersensitivity reaction to an external substance that is normally not harmful to the body. An imbalance between type 2 immune response and regulatory T cells (Tregs) has been found to be effective in immunopathology of allergic diseases. Tregs can inhibit type 2 immune cells such as T helper 2 (Th2), type 2 innate lymphoid cells and IgE-producing B cells; meanwhile, they induce tolerogenic dendritic cells, regulatory B cells and IgG4-producing B cells. Tregs play a critical role in maintaining immune tolerance to allergens that regulate the type 2 immune response in patients with allergic diseases. Allergen-specific immunotherapy (AIT) is the only causal treatment modality to reduce allergic symptoms by altering the immune response to allergens. A key feature of AIT is to induce and maintain immune tolerance to allergens that enhances functionality, while inducing and maintaining Tregs in allergic patients. In this review, we discuss the six subsets of Tregs, natural (nTregs), inducible Treg (iTregs), inducible costimulatory (ICOS ${ }^{+}$Tregs), Tr1, CD8 ${ }^{+}$Tregs and IL-17-producing Tregs, and their role in allergic disease and allergen immune tolerance. We also discuss specific markers of dysregulated Tregs in allergy such as, immunoglobulin-like transcript (ILT) 3, chemoattractant receptor-homologous molecule expressed on Th2 cells (CRTH2) and ST2. These novel molecules on Tregs provide an opportunity for novel treatment strategies aimed at changing the function of Tregs in allergic diseases.
\end{abstract}

Key words: Treg, allergic disease, allergen-specific immunotherapy, AIT, allergy, immune tolerance, IL-10

From:

${ }^{1}$ Swiss Institute of Allergy and Asthma Research (SIAF),

University of Zurich, Davos, Switzerland

2 Allergy and Clinical Immunology, Department of Medicine,

Phramongkutklao Hospital, Bangkok, Thailand

${ }^{3}$ Christine Kühne-Center for Allergy Research and Education

(CK-CARE), Davos, Switzerland

${ }^{4}$ Ankara University School of Medicine, Department of Chest Diseases

Division of Clinical Immunology and Allergic Diseases, Ankara,

Turkey

\section{Introduction}

Allergic diseases are a group of complex disorders caused by inappropriate immune responses towards allergens. Allergy is caused by an imbalance between regulatory cells and type 2 immune responses. ${ }^{1}$ Type 2 -immunity is an immune response induced by an allergen, where naïve $\mathrm{T} \mathrm{CD}^{+}$cells differentiate into T helper (Th) 2 effector cells and is additionally characterized by immunoglobulin (Ig) E-producing B cells, eosinophils, type 2 innate lymphoid cells (ILC2) and activated mast cells and basophils. Type 2 cytokines are interleukin (IL)-4, IL-5, IL-9 and IL-13, which are generally produced by ILC2 and Th2. IL-4 induces Th2 cell differentiation and induces isotype switching to IgE production in B cells. IL-5 is responsible for the maturation and recruitment of eosinophils. ${ }^{2}$ IL-9 is produced by Th9 which induces eosinophilic inflammation, mast cell growth, mucus hypersecretion, and airway hyperresponsiveness (AHR). IL-13 regulates the proliferation of
Corresponding author:

Cezmi A. Akdis

Swiss Institute of Allergy and Asthma Research (SIAF)

Obere Str. $22 \mathrm{CH}-7270$

Davos Platz, Switzerland

E-mail: akdisac@siaf.uzh.ch

IgE-producing B cells, mucus hypersecretion and AHR and opens the epithelial tight junction barrier. ${ }^{3-5}$ Epithelial cells of airways, skin and gut are the first line of defense against allergens. Damaged epithelial cells release alarmin cytokines, such as IL-25, IL-33 and thymic stromal lymphopoietin (TSLP). These cytokines can directly activate ILC2 to produce type 2 cytokines. ${ }^{3,4}$ Moreover, IL-33 and TSLP directly activate mast cells. TSLP stimulates Th0 cells and dendritic cells (DCs) to induce a Th2-like process. TSLP also promotes B cell proliferation. ${ }^{1}$ Other stimuli such as toll-like receptor (TLR) 2 and TLR-4 can also stimulate the release of TSLP from epithelial cells. ${ }^{6,7}$

Regulatory cells are essential in maintaining immunological self-tolerance, in preventing autoimmune diseases and in regulating immune responses to foreign antigens. Regulatory cells induce immune tolerance by producing IL-10, TGF- $\beta$ and 
IL-35. ${ }^{8}$ In addition, they function via surface CTLA-4 and PD1-PDL interaction. IL-10 is an immune-regulatory cytokine with suppressor functions in many effector cells and different types of inflammatory reactions. ${ }^{9,10}$ Current evidence supports the potential role of IL-10-secreting regulatory $\mathrm{T}$ (Treg) and $\mathrm{B}$ (Breg) cells in inducing and maintaining allergen tolerance. ${ }^{11}$ Allergen-specific immunotherapy (AIT) is an immune tolerance inducing treatment that is effective in reducing symptoms of allergic rhinitis, asthma, venom and food allergy. ${ }^{12-19}$ Therefore, it is the only treatment that enhances allergen-specific Treg and Breg cells. ${ }^{20-22}$ An increasing number of allergenspecific Treg and Breg cells during AIT have been associated with the improvement of allergic symptoms in a successful AIT. ${ }^{23-25}$ AIT also induces IgA, IgG2 and IgG4-producing B cells, whereas decrease Th2, ILC2, IgE-producing B cells and mast cells activation. ${ }^{26-29}$ Furthermore, a sustained Treg response after discontinuation of AIT is associated with improved clinical response, decreased eosinophil counts and serum specific-IgE levels, measured during high exposure allergen season. ${ }^{30}$ In this review, we aimed to clarify the underlying mechanisms of Tregs in allergic diseases and allergen immune tolerance, in the light of recent data on the Treg subsets in allergic diseases and AIT.

\section{Treg cells}

Treg cells represent $5-10 \%$ of circulating $\mathrm{CD} 4^{+} \mathrm{T}$ cell population in healthy humans. Treg cells can be classified into natural (nTregs), inducible Treg (iTregs), inducible costimulatory (ICOS ${ }^{+}$Tregs), Tr1, CD8 ${ }^{+}$Tregs and IL-17-producing Tregs (Table 1). It has to be noted here that some of these Treg cell subsets are functionally overlapping or synergize each other. These Tregs share some characteristics, including expression of IL-10 and transforming growth factor-beta (TGF- $\beta$ ). ${ }^{31}$ TGF- $\beta$ regulates $\mathrm{T}$ cell proliferation, differentiation and apoptosis.
The cell surface marker CD25 or IL-2 receptor alpha chain is also expressed on Tregs. ${ }^{32}$ Indeed, IL-2 is the main factor for survival of Tregs, which maintains peripheral immunological tolerance. Forkhead box P3 (FOXP3) is a transcription factor that controls the differentiation and functions of $\mathrm{CD} 4^{+} \mathrm{CD} 25^{+}$ Tregs. ${ }^{33}$ FOXP3 also induces the expression of anti-inflammatory cytokine IL-10 through a mechanism in cooperation with STAT $3 .{ }^{34}$

\section{Natural Treg cells}

The thymic or natural Treg (nTreg) cells $\left(\mathrm{CD} 4^{+} \mathrm{CD} 25^{+}\right.$ $\mathrm{CD} 27^{-} \mathrm{FOXP}^{+}$) have originated from those that have highaffinity interactions with self-peptide/MHC class II complexes during $\mathrm{T}$ cell development in thymus. nT-regs produce IL-10 and TGF- $\beta$ and represent one of the most substantial subsets of Tregs. The role of Tregs in the immunopathology of allergic diseases is shown in Figure 1. Tregs can suppress proliferation and activation of effector Th cells, such as Th2 or Th17. Moreover, nTregs play a role in allergen-specific immune reactions, including suppression of inflammatory DCs that activate the formation of effector $\mathrm{T}$ cells, while supporting tolerogenic DCs. Tregs can inhibit functions and migration of Th1, Th2, Th9 and Th17 cells. In addition, Tregs can suppress allergen-specific IgE production, while inducing IgG4-secreting B cells and IL-10-producing Bregs. Furthermore, Tregs can suppress the activation of ILC2s, NKT cells, mast cells, basophils, and eosinophils. ${ }^{35}$

Tregs have suppressive mechanisms by producing inhibitory cytokines such as IL-10, IL-35 and TGF- $\beta$. FOXP $3^{+}$Tregs show a variety of different mechanisms for implementing their suppressive actions. They release perforin and granzyme A, B and $\mathrm{K}$ to induce cytolysis of $\mathrm{T}, \mathrm{B}$, and NK cells; with cell-cell contact they compete with effector $\mathrm{T}$ cells and antigen-presenting cells for stimulatory signals such as CTLA-4, PD-1,

Table 1. Characterization of Treg subsets defined by specific marker and cytokines

\begin{tabular}{|c|c|c|}
\hline Subset & Specific marker & Cytokine production \\
\hline natural Treg (nTreg) & $\mathrm{CD}^{+}{ }^{+} \mathrm{CD} 25^{+} \mathrm{CD} 127^{-} \mathrm{FOXP}^{+}$Helios $^{+} \mathrm{CD} 39^{+} \mathrm{CD} 3^{+} \mathrm{CTLA}^{+} \mathrm{Nrp}^{+}$ & IL-10, TGF- $\beta$, IL-35 \\
\hline induced Treg (iTreg) & $\mathrm{CD}^{+} \mathrm{CD}^{2} 5^{+} \mathrm{CD}_{127}{ }^{-} \mathrm{FOXP}_{3}{ }^{+} \mathrm{CD} 39^{+} \mathrm{CD} 3^{+} \mathrm{CTLA}^{+}$ & IL-10, TGF- $\beta$, IL-35 \\
\hline Inducible costimulatory Treg (ICOS ${ }^{+}$Treg) & $\mathrm{CD}^{+}{ }^{+} \mathrm{CTLA}^{+} \mathrm{FOXP}^{+} \mathrm{ICOS}^{+}$ & IL-10, TGF- $\beta$ \\
\hline IL-10-producing $\operatorname{Tr} 1$ cells $(\operatorname{Tr} 1)$ & $\mathrm{CD}^{+}{ }^{+} \mathrm{CD} 25^{+} \mathrm{LAG}^{+} \mathrm{CD} 4 \mathrm{~b}^{+}$ & IL-10 \\
\hline $\mathrm{CD}^{+}$Treg & $\mathrm{CD}^{+}{ }^{+} \mathrm{CD} 25^{+} \mathrm{FOXP}^{+} \mathrm{CD}^{2} 8^{+} \mathrm{CTLA}-4^{+} \mathrm{CD} 122^{+} \mathrm{CD} 137^{+} \mathrm{CD} 103^{+}$ & IL-10, TGF- $\beta$, IL- 16 , IFN- $\gamma$ \\
\hline IL-17A-producing Treg cells & $\mathrm{CD}^{+} \mathrm{FOXP}^{+} \mathrm{ROR} \mathrm{t}^{+} \mathrm{CCR}^{+} \mathrm{CD} 49 \mathrm{~d}^{+} \mathrm{IL}-1 \mathrm{R}-\beta^{+} \mathrm{CD} 161^{+} \mathrm{HLA}^{-\mathrm{DR}^{-}}$ & IL-10, IL-17A \\
\hline
\end{tabular}

Table 2. Molecular and functional features of Tregs

\begin{tabular}{lc}
\multicolumn{1}{c}{ Treg markers } & Mechanism of suppression \\
\hline CD25, CTLA-4, PD-1 & Suppressive cytokines: IL-10, TGF- $\beta$, IL-35 \\
TGF- $\beta$, IL-10, CD49b, LAG-3, LAP & Metabolic disruption: CD25, cAMP, ADR2, HR2, CD39, CD73 \\
Granzyme A, B and K, CD122, CD103 & Target molecule DCs: CTLA-4, PD-1, TGF- $\beta$ R, IL-10R \\
\hline ICOS, GARP, Neuropilin-1, Gpr83, ECM1, Helios, GITR & Cytolysis, Granzymes A, B and K perforin \\
\hline
\end{tabular}


Suppression of inflammatory DCs and induction tolerogenic DCs through cell-cell contact, cytokines and metabolic disruption
Suppression of effector Th cells through cytokines, metabolic disruption, cytolysis and cell-cell contact (CTLA-4 and ICOS)

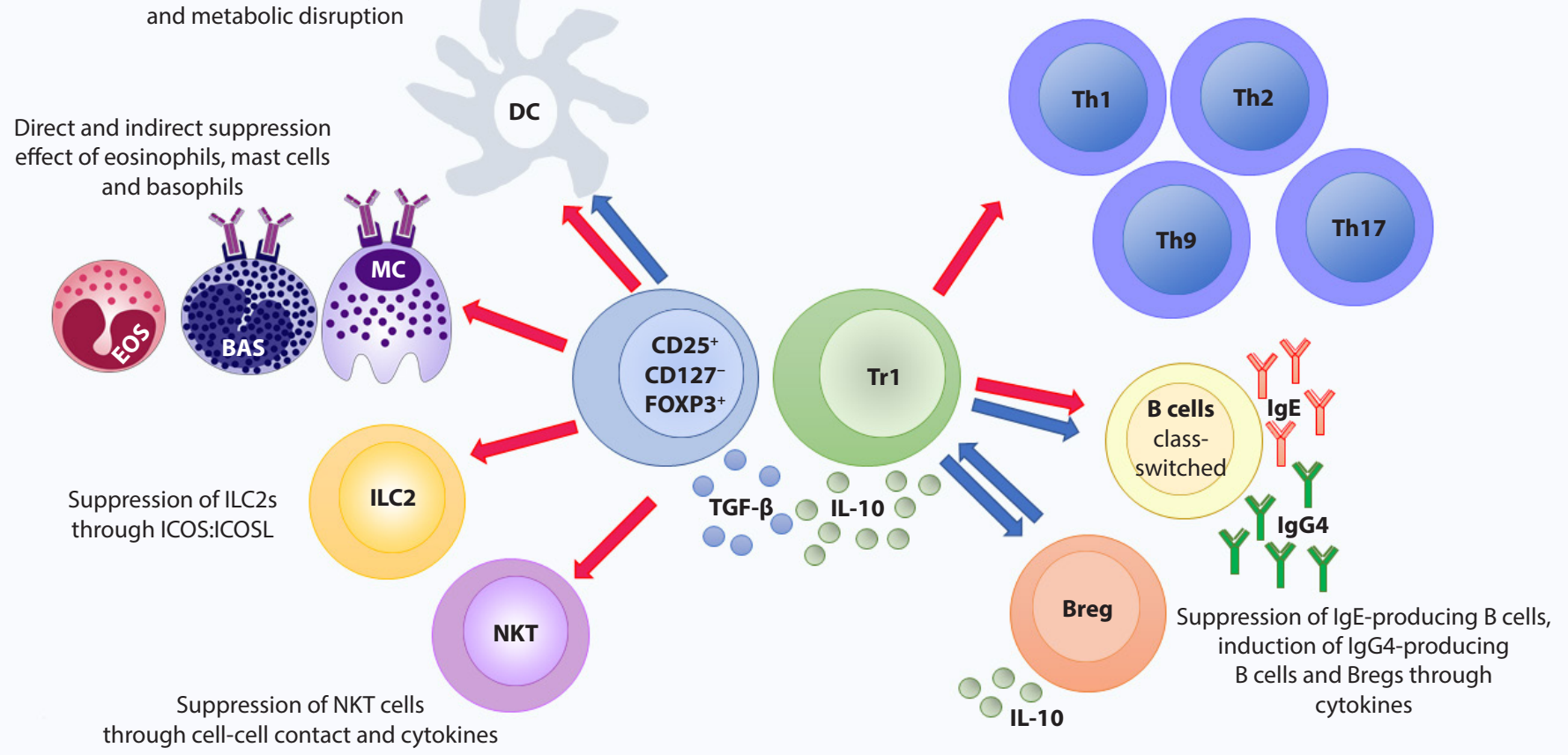

Figure 1. Tregs in allergic diseases. Tregs inhibit type 2 immune responses and contribute to the control of allergic diseases through several pathways. Red arrows display the regulatory and suppressive effects that Tregs exert on inflammatory dendritic cells (DCs), mast cells, basophils, eosinophils, type 2 innate lymphoid cells (ILC2), NKT cells, effector T helper cells, and IgE-producing $B$ cells. Blue arrows show the contribution of Tregs to the induction allergen immune tolerance that Tregs effects on tolerogenic DCs, Bregs and IgG4-producing B cells.

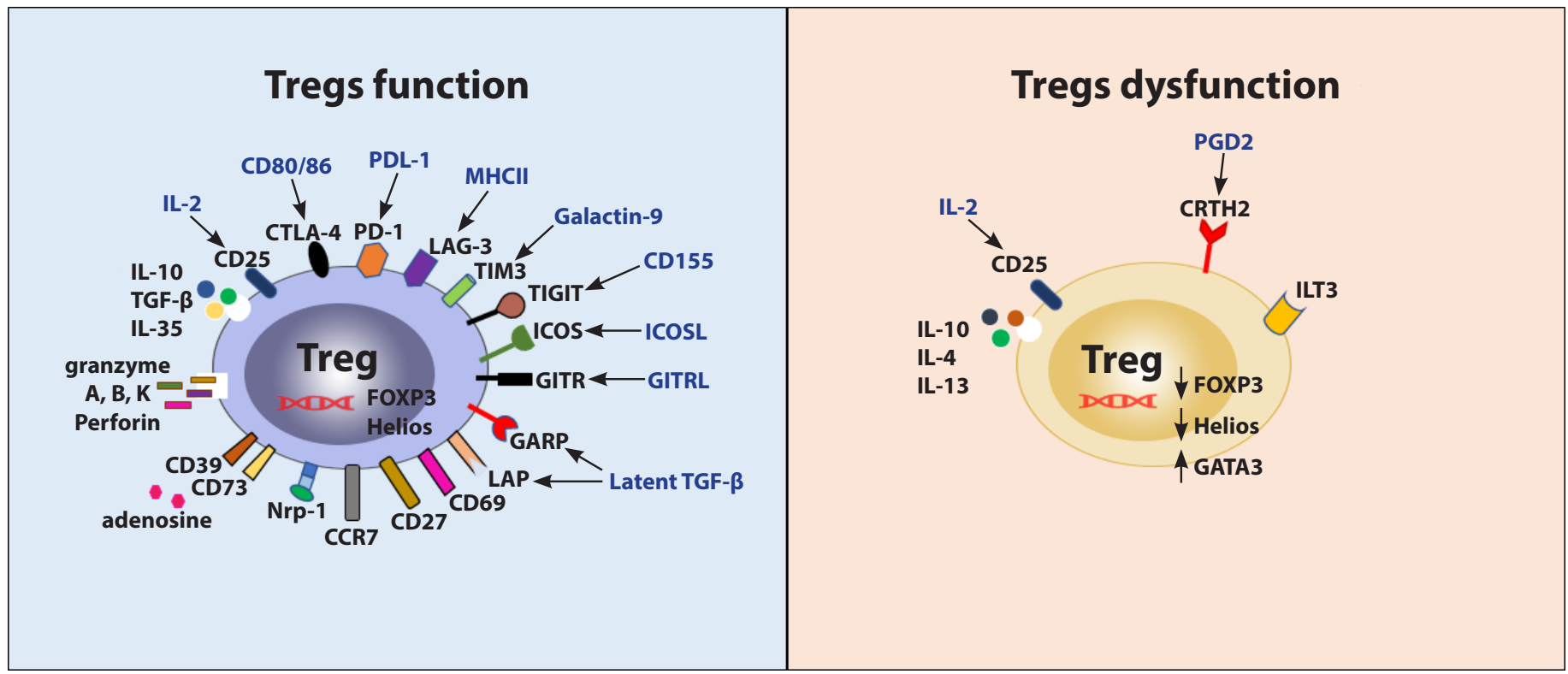

Figure 2. The marker of functional and dysfunctional Tregs. Tregs have high expression levels of surface markers associated with suppression such as CTLA-4, PD-1, LAG-3, TIM-3, LAP, GARP, TIGIT, ICOS, GITR, CD39, CD73, CD69, CD27, CCR7 and Nrp-1. Helios is a transcription factor that is upregulated in activated Tregs. CRTH2 and ILT3 are expressed on Tregs and related with the inadequate Treg suppression to effector T cells. The expression of transcription factor decreased FOPX3 and Helios, whereas increased GATA3 were found in impaired immunosuppression Tregs. 
lymphocyte activation gene 3 (LAG3) and TIM3; and they use metabolic disruption mechanisms such as cAMP, adenosine receptor 2, histamine receptor 2 (HR2), CD39 and CD73. ${ }^{35}$ Functional suppressor Tregs also express CD27, CCR7, T cells expressing the coinhibitory molecule (TIGIT), glycoprotein A repetitions predominant (GARP), inducible costimulatory (ICOS), latency associated peptide (LAP), glucocorticoidinduced tumor necrosis factor-related receptor (GITR) and CD69 (Table 2 and Figure 2). ${ }^{11}$

Helios $^{+}$and Helios ${ }^{-}$Tregs are phenotypically and functionally distinct and express unique TCR repertoires. ${ }^{36}$ Helios is a marker of $\mathrm{T}$ cell activation and expression. ${ }^{37}$ Helios also enhances induced Treg cell function in collaboration with FOXP3. ${ }^{38}$ The percentage of FOXP ${ }^{+}$Helios $^{+}$Tregs in healthy controls and patients with stable allergic asthmatic was higher than in patients with exacerbated asthma. ${ }^{39}$ AIT was shown to increase allergen-specific FOXP $3^{+} \mathrm{Helios}^{+}$Tregs and that correlates with the reduction of allergic symptoms. ${ }^{23}$ Furthermore, the presence of local $\mathrm{FOXP} 3^{+} \mathrm{CD} 25^{+}$Tregs in the nasal mucosa increases after AIT. They are associated with clinical efficacy and suppression of seasonal allergic inflammation. In a mouse model, AIT also induces systemic and local Tregs in skin of atopic dermatitis mice that correlate with the efficacy of AIT. ${ }^{40}$ Thus, it can be said that the concept of local allergen tolerance in the peripheral tissues may depend on Treg responses. ${ }^{41,42}$

In developing Tregs in the thymus, a framework of Tregsspecific epigenetic marks is anchored. This epigenetic framework is accompanied by the expression of FOXP3, which together shape the function and phenotype of mature thymusderived Tregs. ${ }^{43}$ The recent study in nTregs showed genes with Treg-specific DNA hypomethylation tend to be upregulated in Tregs in the steady-state. In contrast, the genes with FOXP3 binding regions tend to be downregulated in activated Tregs. ${ }^{44}$ Thus, the two events seem to display different but collateral roles in Treg-specific gene expression.

\section{Induced Treg cells (iTregs)}

iTregs are peripherally induced Tregs by abundant TGF- $\beta$, and retinoic acid that is produced by DCs and macrophages. ${ }^{45,46}$ iTregs and nTreg express similar levels of shared Treg cell markers, such as FOXP3, CTLA-4, GITR, ICOS, CD103 and CD25. ${ }^{47}$ Helios and neuropilin-1 (Nrp-1) are highly expressed in nTregs compared to iTregs and they are used to distinguish nTregs from iTregs. ${ }^{48,49}$ Moreover, iTregs are known to be less stable than nTregs, because they may lose FOXP3 expression and produce cytokines, such as IFN- $\gamma$ and IL-17 because of local inflammatory conditions and innate immune response stimulating substances in the microenvironment. ${ }^{50}$ iTregs and nTregs can be converted from their suppressor property into pathogenic effector cells. These effects can be mediated in different pathways such as IL-6-induced IL-17 production in iTregs but not in nTregs. ${ }^{51}$ In a mouse allergic asthma-like lung inflammation model, iTregs are significantly more tolerogenic than nTregs. iTregs reduce active Th2 response by $72-86 \%$, whereas nTregs reduce these responses by $41-56 \% .^{52}$ Furthermore, increased demethylation of the Treg-specific demethylation region in the Foxp3 locus in nTregs but not iTregs was reported in mice study. ${ }^{53}$
A recent study in atopic children showed that the number of circulating memory Tregs $\left(\mathrm{CD} 45 \mathrm{RA}^{-}\right)$were higher compared to healthy children. ${ }^{27}$ However, the study did not investigate the FOXP3 expression in Tregs and Treg suppressor function. Myeloid-derived suppressor cells $\left(\mathrm{CD} 45^{+} \mathrm{CD} 33^{+} \mathrm{CD} 14^{+}\right.$ HLA-DR ${ }^{-/ l o w} \mathrm{CD}^{-} 5^{-}$) can suppress effector $\mathrm{T}$ cells and promote Treg expansion. In adult asthmatic patients, the percentage of myeloid-derived suppressor cells is small, compared to healthy controls and has been associated with decreased FOXP $3^{+}$Tregs in peripheral blood. ${ }^{54}$

\section{Inducible costimulatory (ICOS) ${ }^{+}$Treg cells}

ICOS has significant homology with the co-stimulatory molecule CD28 and the immune- checkpoint CTLA-4. ICOS ${ }^{+}$ and ICOS $^{-}$Tregs are different subsets due to their cytokine production capacity. $\mathrm{ICOS}^{+}$Tregs can produce large amounts of IL-10, moderate amounts of TGF- $\beta$ and another cytokines such as IL-17 and IFN- $\gamma \cdot{ }^{55,56}$ ICOS signals together with FOXP3 and CTLA-4 and contributes to the survival and suppressive functions of Tregs. ${ }^{57,58}$ Tregs can suppress ILC2s through ICOS:ICOS-L to control airway inflammation together with the suppressor cytokines TGF- $\beta$ and IL-10..$^{59,60}$ The number of active ICOS ${ }^{+}$Tregs was higher in the children living in traditional farms, with a low risk of atopy and asthma, compared with the children living in modern farms. ${ }^{61}$

\section{Type 1 regulatory $T$ cells $(\operatorname{Tr} 1)$}

$\operatorname{Tr} 1$ cells secrete IL-10, which are not dependent on FOXP3 expression for their function. LAG3 and CD49b markers have been identified as additional cell-specific markers for human Tr1 cells. ${ }^{62-64}$ IL-10 can suppress Th2-type and Th17 cells. Besides, IL-10 can inhibit cytokine production of eosinophils, basophils, mast cells, antigen-presenting cells and dendritic cells. Moreover, IL-10 can support B cells that induce the development of $\operatorname{Tr} 1, \mathrm{Br} 1$ cells, and IgG4 upon differentiation of Br1 cells to plasma cells. IgG4 reduces allergic responses by blocking the allergen binding of $\operatorname{IgE} .^{65}$ Moreover, it was suggested that IgG4 can drive M2a macrophage to regulatory M2b-like phenotype. ${ }^{66}$

Patients with allergic diseases have lower percentage of antigen-specific $\operatorname{Tr} 1$ cells in peripheral blood compared to healthy subjects. ${ }^{67}$ It was demonstrated that peanut-specific

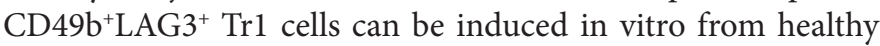
controls and patients with peanut allergy, but $\operatorname{Tr} 1$ cells from patients with peanut allergy are functionally defective. ${ }^{68}$ Der p 2-specific Tr1 cells can be supported by Der p 2-pulsed DC-10, which can suppress Derp 2-specific Th2 cells. ${ }^{69} \operatorname{Tr} 1$ cells implicate to restore tolerance in allergy. Der $\mathrm{p} 1$-specific Tr1 cells increase during AIT in patients allergic to house dust mites, correlated with the developing clinical tolerance. ${ }^{23}$ Moreover, AIT may enhance Bet v 1-specific $\operatorname{Tr} 1$ cells associated with low skin prick test reactivity and reduced clinical symptoms to birch pollen. ${ }^{70}$ IL-10 mRNA levels in whole blood cells remarkably correlate with house dust mite allergen immunotherapy efficacy. ${ }^{71} \operatorname{Tr} 1$ Treg cells have been shown to be the main subset in high dose allergen tolerance models, such as bee venom allergen tolerance in multiple bee sting receiving bee keepers and cat allergen tolerance in cat owners. ${ }^{64,72}$ 


\section{$\mathrm{CDB}^{+}$Treg cells}

$\mathrm{CD}^{+}$Tregs can effectively block the overreacting immune response and maintain the body's immune homeostasis. This cell subset is generally identified as $\mathrm{CD} 8^{+} \mathrm{CD} 25^{+}$cells and other markers including FOXP3, CD28, CTLA-4, CD122, CD137 and $\mathrm{CD} 103$ have been described. ${ }^{73,74}$ The cytotoxicity of $\mathrm{CD}^{+}$ Tregs is due to the expression of MHC class $\mathrm{Ib}$ molecules, more specifically Qa-1 in mice and HLA-E in humans. ${ }^{75} \mathrm{CD}^{+}$ Tregs secrete various cytokines and chemokines, including IL10 , TGF- $\beta$, IL-16, IFN- $\gamma$, and chemokine (C-C motif) ligand $4 .{ }^{75} \mathrm{CD}^{+}$Tregs stimulate tolerogenic antigen-presenting cells (APCs) by upregulating the expression of immunoglobulinlike transcript (ILT) 3 and ILT4. Moreover, $\mathrm{CD} 8^{+}$Tregs exhibit an inhibitory function by CTLA- 4 dependent cell-contact. Tonsillar FOXP ${ }^{+} \mathrm{CD}^{+}$Treg phenotype exhibits high CTLA4 and $\mathrm{CD} 45 \mathrm{RO}$ and low expression of CD127 and CD69. ${ }^{74}$ $\mathrm{FOXP3}^{+} \mathrm{CD}^{+}$Tregs may inhibit the proliferation of $\mathrm{CD} 4^{+} \mathrm{T}$ cells in co-cultures. ${ }^{74}$ The frequency of $\mathrm{CD} 8^{+} \mathrm{CD} 25^{+} \mathrm{FOXP}^{+}$ cells in peripheral blood was lower in asthmatic patients compared to healthy controls. ${ }^{76}$ In addition, the percentage of $\mathrm{CD}^{+}$Tregs correlated with peak expiratory flow rate and severity of asthma. ${ }^{76} \mathrm{~A}$ significant increase was observed in Der p 2-specific $\mathrm{CD}^{+} \mathrm{FOXP3}^{+}$Treg cells expressing IL-10 and granzyme $\mathrm{B}$, after house dust mite specific immunotherapy. ${ }^{77}$ Furthermore, AIT expands $\mathrm{CD} 8^{+} \mathrm{CD} 25^{+} \mathrm{CD} 137^{+}$Tregs in the circulation and the nasal mucosa of the patients with allergic rhinitis. ${ }^{78}$ Thus, $\mathrm{CD} 8^{+}$Tregs may cooperate with $\mathrm{CD} 4^{+}$Tregs to suppress the type 2 immune response by induced apoptosis of Th2 cells.

\section{IL-17A-and IFN- $\gamma$-producing Treg cells}

IL-17A-producing $\mathrm{CD}^{+}{ }^{+} \mathrm{FOXP}^{+}{ }^{+}$Tregs express ROR $\gamma \mathrm{t}$. ROR $\gamma t$ is the Th17-specific transcription factor. Th17A producing Tregs can transform from conventional $\mathrm{CD}^{+} \mathrm{FOXP3}^{+}$ Treg cells. IL-6, IL-21, IL-23, and IL-1 $\beta$ are required to the differentiation of conventional Tregs into IL-17A-producing Tregs. ${ }^{79}$ Expression of CCR6, CD49d, IL-1R- $\beta$, CD161, and the absence of HLA-DR, are used to identify cell surface markers of IL-17A-producing FOXP3 ${ }^{+}$Treg cells. ${ }^{80}$ IL-17A-producing $\mathrm{CD}^{+} \mathrm{FOXP}^{+}$Tregs can suppress the proliferation of $\mathrm{CD} 4^{+}$ effector $\mathrm{T}$ cells through a cell-cell contact mechanism. ${ }^{81} \mathrm{Al}-$ though, ROR $\gamma \mathrm{t}$ and FOXP3 expression have recently been associated with a reduced suppression function. ${ }^{82}$ The frequency of IL-17A-producing Tregs in allergic patients is increased compared to healthy controls ${ }^{83}$ In addition, IL-17A and ROR $\gamma$ t expression was higher in patients with persistent allergic symptoms than in those with intermittent allergic symptoms, whereas FOXP3 expression was decreased. ${ }^{84}$ Immunological changes in patients treated with AIT in the build-up phase are presented with a decrease of Th1, Th17 and CCR6 ${ }^{+}$IL-17 ${ }^{+}{ }^{\text {FOXP3 }}{ }^{+}$Tregs. ${ }^{85}$

IFN- $\gamma$ plays a vital role in both inductions of Tregs as well as immunosuppression mediated by IFN- $\gamma$-producing Tregs. IFN- $\gamma$-producing Tregs are only $0.04 \%$ of all $\mathrm{CD}^{+} \mathrm{T}$ cells in the circulating of healthy individuals and increases significantly during an immune response. ${ }^{86}$ IFN- $\gamma^{+}$Tregs are induced by IFN- $\gamma$ and IL-12. ${ }^{87}$ Type 1 interferon signaling attenuated Treg function in viral infection, tumor immunity and organ transplant. ${ }^{88,89}$ However, the role of IFN- $\gamma$-producing Tregs in allergic diseases is required further study.

\section{Dysregulated regulatory $\mathrm{T}$ cells}

Dysregulated Tregs seems to play an essential role in the development or chronicity of allergic diseases. In patients with allergy and asthma, the FOXP3 gene decreased compared to healthy controls..$^{90}$ In addition, several reports indicate that FOXP3 polymorphisms and impaired Tregs function involve in the development of allergy and asthma. ${ }^{91,92}$ Infants with food allergy presented low number of nTregs at birth. ${ }^{23,93}$ Moreover, cesarean section was associated with a temporary reduction in nTregs at birth. ${ }^{93}$ In allergic children, FOXP $3^{+}$Treg cell maturation was significantly delayed compared to mature and healthy children. ${ }^{94}$ In vitro experiments have shown that, the suppressive function of Tregs in the peripheral blood of allergic patients is reduced compared to Treg cells of healthy controls. ${ }^{95,96}$ In patients with allergic asthma, FOXP3 ${ }^{+}$Tregs were found to be less in bronchoalveolar lavage and have impaired regulatory functions. ${ }^{97}$ IL-27 is essential for controlling inflammatory responses of FOXP3 ${ }^{+}$Treg functions. In animal models, the intranasal administration of IL-27 could attenuate airway inflammation due to upregulated Th1 cells and Tregs because of repairing the STAT1 pathway. ${ }^{98}$ Tregs of asthmatic patients exhibited blunted STAT1 phosphorylation following IL-27 stimulation. ${ }^{99}$ The altered IL-27 response in Tregs may indicate inadequate Treg functions. Recently reported findings suggest that AIT restores the suppressive capacity of FOXP3 ${ }^{+}$ Tregs in patients with aeroallergen allergy. ${ }^{100}$

Tregs can lose their FOXP3 expression and acquire the ability to produce the corresponding Th cytokines depending on their microenvironment. ${ }^{101}$ GATA-3 expression in Tregs may contribute to Th2 responses by switching Tregs into Th2 cells under type 2 environment. In the animal model, GATA3 was relevant regulators of Treg plasticity that inhibit Tregs from becoming novel APC-Tregs. ${ }^{102}$ The recent study in asthmatic patients revealed that the frequency of Tregs decreased in asthmatic patients with an impaired immunosuppression function and a Th2-like phenotype. That may be due to overexpression of GATA3 and FOXP3 ${ }^{103}$ In the patients with immune dysregulation polyendocrinopathy enteropathy X-linked (IPEX) syndrome, M3701FOXP3 mutation generated Th2like Treg cells which expressing GATA3 and Th2 cytokines. Besides, this Tregs mutation had increased chromatin interaction at the Th2 locus. ${ }^{104}$

ILT3 expression in FOXP3 $3^{+}$Treg cells represents a distinct subset of Tregs. Several lines of evidence demonstrate that they represent a dysregulated $\mathrm{T}$ reg cell subset. ILT3 ${ }^{+} \mathrm{FOXP3}^{+}$ Tregs cannot control the maturation of DCs that increase Th2 response. ${ }^{105}$ Protein kinase CK2 enables Tregs to suppress the type 2 immune response. Deletion of the beta subunit of CK2 results in proliferation of a subpopulation of Tregs characterized by the expression of the inhibitor receptor ILT3. ${ }^{105}$ The incidence of $\mathrm{ILT3}^{+}$Tregs in healthy controls is significantly lower than in allergic patients. ${ }^{105}$ Recently, we reported that ILT3 $^{+}$Tregs decreased significantly during AIT, although the patients showed allergen tolerance. ${ }^{23}$ Moreover, we also found that ILT3 $3^{+}$Tregs show compromised suppressive function due to low FOXP3 and Helios expression. ${ }^{23}$ 
Another dysfunctional Treg cell subset is chemoattractant receptor-homologous molecule expressed on Th2 cells (CRTH2) ${ }^{+}$Tregs. These cells are Th2-like Tregs that combine inhibitory function and Th2-cytokine production. CRTH2 is a receptor that binds to the ligand prostaglandin D2 (PGD2) and binds to a surface marker of Th2 cells. In an in vitro experiment, $\mathrm{CRTH} 2^{+}$Tregs presented less suppressive function compared to CRTH2- Tregs. ${ }^{106}$ Moreover, CRTH2 ${ }^{+}$Tregs have been shown to produce greater amounts of IL- 4 than CRTH2Tregs after PGD2 stimulation but there was no significant difference found in IL-10 levels. In addition, patients with allergic asthma had more $\mathrm{CRTH} 2^{+}$Tregs in peripheral blood than healthy controls. ${ }^{106}$ Moreover, the number of CRTH2 ${ }^{+}$Tregs in peripheral blood is correlated with the ability to control asthma. After therapy of asthma patients, CRTH2 ${ }^{+}$Treg cell count and activated $\mathrm{CRTH}_{2}{ }^{+}$Treg response to PGD2 stimulation are significantly decreased in patients with allergic asthma in parallel to improved lung functions. The use of IL-4 receptor alpha blockade in AIT has been a major question. It was demonstrated that AIT combined with IL-4 receptor alpha blockade can decrease Th2-biased Tregs $\left(\mathrm{ST}^{+}{ }^{+} \mathrm{FOXP}^{+}{ }^{+} \mathrm{GATA}^{+}{ }^{+}\right)$ in allergic mice model. ${ }^{107}$

IL-4 is a cytokine that induced naïve T cells to Th2 cells and activated Th2 to secrete IL- 4 in a positive feedback loop. In the Tregs study, IL- 4 inhibits TGF- $\beta$-induced FOXP $3^{+}$Tregs generates. ${ }^{108}$ IL-4 inhibited Tregs differentiation due to suppress the expression indoleamine 2,3-dioxygenase on $\mathrm{CD}_{103^{+}}$ DCs. ${ }^{109}$ The other reported in the animal study, IL-4 had affected the function of Tregs by 1) protect $\mathrm{T}$ effector from Tregmediated immune suppression, 2) IL-4 deprivation impaired the ability of Tregs to modulate the immune response, 3) IL-4 was associated with increased cell survival and granzyme expression of Tregs. ${ }^{110}$

In the animal model, loss of liver kinase B1 (LKB1) in Tregs has been shown to disrupt cell metabolism and function in mice leading to a fatal inflammatory disease characterized by excessive Th2 immune response. ${ }^{11}$ Expression of the IL33 receptor ST2 has been demonstrated in FoxP3 ${ }^{+}$Tregs in mice. ${ }^{112}$ When exposed to IL-33, Tregs were found to upregulate GATA3 expression, as well as ST2 expression and produce type 2 cytokines. ${ }^{112}$ Moreover, Tregs lose their capacity to suppress effector T cells in the presence of IL-33. ${ }^{12}$ However, other reports have presented that $\mathrm{ST}^{+}$Tregs are superior to ST2- Tregs in suppressing IL-33 independent in vitro CD4 ${ }^{+} \mathrm{T}$ cell proliferation. ${ }^{113}$ Data on ST2 expression in Tregs have not been reported in allergic patients. Bcl6 is required for the development of $\mathrm{T}$ follicular helper cells and $\mathrm{T}$ follicular regulatory (Tfr) cells. In mice, allergic airway inflammation, Bcl6 and Blimp1 played dual roles in regulating Tfr-cell activity in the germinal center and the development of ST2 ${ }^{+}$Tregs. ${ }^{114}$ TCR-activated posttranslational modification by O-linked $\mathrm{N}$-acetylglucosamine (O-GlcNAc) stabilizes FOXP3 and activates STAT5. Treg cells with O-GlcNAc-deficiency usually develop but exhibit modestly decreased FOXP3 expression and subsequently ameliorate Treg cell dysfunction in O-GlcNAc deficient mice. ${ }^{115}$

\section{Treg cells in atopic dermatitis}

Atopic dermatitis (AD) occurs from the combination of an altered skin barrier and dysregulated immune reactions, mainly driven by Treg cell dysfunction. ${ }^{116}$ The term autoallergy describes autoimmunity in $\mathrm{AD}$ patients, with antigen-specific IgE raised against self-proteins as a hallmark. This phenomenon has been found in 23 to $91 \%$ of the patients with AD. ${ }^{117}$ These skin autoallergens were able to induce T-cell proliferation in AD patients. Tregs constitute between $20-80 \%$ of $\mathrm{CD}^{+}$ $\mathrm{T}$ cells in the skin at steady-state. ${ }^{118}$ Skin-homing Tregs also play a critical role in mitigating the reactivity of immune cells, secreting high levels of cytokines that promote tolerance. ${ }^{119}$ Study of AD patients in China revealed that the number of FOXP3 $^{+}$Tregs before receiving treatment correlated with disease severity, whereas IL- $10^{+}$Tregs did not show related to disease severity. ${ }^{120}$ The retinoic acid receptor-related orphan receptor a (ROR $\alpha)$-expressing in skin resident Treg was significant for suppressing type 2 cytokines that related allergic skin inflammation. ${ }^{121}$

\section{Treg cells in food allergy}

IgE-mediated food allergy is a type 2 immune response that the prevalence is increasing in the children as a direct consequence of reduced tolerance to food antigens. In ovalbumin-sensitized mice suggested that administration of high doses of allergens through the oral route predominantly induced deletion of antigen-specific-effector $\mathrm{T}$ cells, whereas administration of low doses favored the generation and expansion of antigen-specific Tregs. ${ }^{122}$ The frequency of Tregs is associated with the maintenance of tolerance in food allergy. Studies in young atopic children proposed that food-allergic children have lower percentages of $\mathrm{FOXP}^{+}$Tregs compared with healthy controls of similar age. ${ }^{123}$ Moreover, age-related increases in CCR6 expression on Tregs were observed in healthy controls but not food-allergic children, which may be essential for Tregs migration to peripheral sites of inflammation in the maintenance of tolerance. ${ }^{123}$ Likewise, the infant with cow milk allergy was related to decreased the number of Tregs and vitamin D levels. ${ }^{124}$ The higher frequency of cow milk allergen-specific FOXP3 Tregs correlated with a phenotype of mild clinical disease and favorable prognosis. ${ }^{125}$

Tregs play a major role in oral tolerance, and the large piece of evidence has demonstrated Tregs implicated in the success of oral immunotherapy (OIT). ${ }^{126}$ Oral tolerance could suppress experimental food allergy through the development of antigen-specific FOXP3 ${ }^{+}$Tregs in mice. ${ }^{127}$ Recent findings demonstrate that oral tolerance can be induced in the tonsils through the generation and maintenance of functional allergen-specific Tregs. ${ }^{128}$ Tonsil pDCs able to generate functional FOXP3 ${ }^{+}$Tregs with suppressive properties from naive $\mathrm{T}$ cells. Allergen-specific FOXP3 ${ }^{+}$Tregs were found to be high in human tonsils compared to peripheral blood. ${ }^{128}$ Syed et al. reported that hypomethylation of FOXP3 and increased Treg function in patients with oral tolerance during peanut OIT. ${ }^{129}$ It was associated with long-term protection from food anaphylaxis. 
Patients with Wiskott-Aldrich syndrome (WAS) are deficient in WAS protein (WASP). These patients usually present with autoimmunity and elevated levels of serum IgE that is pronounced with food allergy. The study in WASP-deficient mice showed the deletion of WASP in $\mathrm{FOXP}^{+}$Tregs resulted in more severe Th2-type intestinal inflammation. ${ }^{130}$ Loss of WASP was phenotypically associated with increased GATA3 expression in effector memory FOXP $3^{+}$Tregs. ${ }^{130}$

\section{Treg cells and microbiota}

The hygiene hypothesis is linked between Tregs and microbiota. Many studies have revealed that growing up in rural areas protects from allergic disorders, possibly by a relative increase in bacterial or fungal diversity. ${ }^{131}$ The experiment in mice showed that low-dose exposure to lipopolysaccharide (LPS), a cell-wall component of gram-negative bacteria, has protective effects in a mouse model of house dust mite allergic lung inflammation. ${ }^{132}$ The mice raised under germ-free conditions that show drastically reduced frequencies of Tregs in the gut. ${ }^{133}$ The bacteria in the gut have an impact on the immune system. In murine studies, identified individual bacterial strains such as Bacteroides fragilis and clostridium strains had been directed the development of $\mathrm{FOXP}^{+}$Tregs and $\operatorname{Tr} 1$ cells. ${ }^{134,135}$ The other mechanism is the fermentation of complex carbohydrate fibers by the microbiota leads to the production of short-chain fatty acids (SCFA). Butylate is a SCFA that had been shown to enhance the generation of Tregs. ${ }^{136}$ Butyrate supplementation enhanced OIT-induced desensitization of basophils and mast cells and Treg functionality in mice experiment. ${ }^{137}$

The recent study in Finland and Estonia reported that an infant Treg phenotype characterized by high Treg frequency and increased the highly activated Tregs. ${ }^{138}$ These changes in Treg population associated first with the relative abundance of Bifidobacterium longum followed by increasing colonization with butyrate-producing bacteria. High bifidobacteria and butyrate-producing bacteria abundance in the neonatal microbiota seems to be beneficial the protection of allergic disease.

Probiotic is live microorganisms that can act as promoters of an adequate balance in the gut microbiota to improve allergic symptoms and prevent the development of allergies. ${ }^{139}$ Administration of probiotics include L. acidophilus, L. casei, Lactobacillus reuteri, Bifidobacterium bifidium, and Streptococcus thermophilus which associated with upregulated Tregs population and increase the suppressor activity of Treg function. ${ }^{140}$ Moreover, probiotic supplement with Bifidobacterium infantis 35624 has been reported to increase the percentage of peripheral FOXP3 ${ }^{+}$Tregs in the human study. ${ }^{141}$ Probiotics are used as an adjuvant in AIT to improve clinical efficacy. ${ }^{142}$ In clinical studies, the addition of probiotics with Lactobacillus rhamnosus GG to sublingual immunotherapy (SLIT) improved symptom scores and the induction of Tregs after 5 months of treatment. ${ }^{143}$ The use of probiotics in the treatment of allergic diseases is very promising but needs more studies to support the data.

\section{Treg-based therapy in allergic disease}

Treg-base therapy are a various study in oncology, transplantation and autoimmune disease. A cure for the allergic disease is imagined that increasing allergen-specific Tregs to restrain IgE-producing allergen-specific memory B cells and plasma cells. The study in the murine model showed a low dose IL-2/anti-IL-2Ab complex combined with AIT could augment more $\operatorname{Tr} 1$ cells than AIT alone. ${ }^{144}$ Also, nasal allergen-CpG immunotherapy enhanced $\operatorname{Tr} 1$ in mice model. ${ }^{145}$ In atopic dermatitis, Treg-base therapy might contribute to repair of the skin barrier, with a subsequent decrease in the local availability of autoallergens. ${ }^{146}$ The chimeric antigen receptor (CAR) approach is engineered as a target protein antigen. The engineered allergen-specific T-regulatory cells to target B cell antibody receptor can provide clinical protection against severe allergic reactions in individuals already IgE-sensitized to ovalbumin in mice study. ${ }^{147}$

\section{Update on Tregs in allergic disease}

IL-35-inducible Tregs (iTr35) have been reported as a new subset of inducible Tregs. IL-35 can suppress IL-5 and IL-13 production by ILC2 and Th2 cytokines-producing T effector cells. ${ }^{148}$ IL-35 also inhibited CD40L-, IL-4-, and IL-21-mediated IgE ${ }^{+}$B cells. ${ }^{18}$ Moreover, iTr35 cells can suppress Th2 cell proliferation and cytokine production. ${ }^{148}$ Notably, IL-35 levels and iTr35 cell counts were increased in patients receiving SLIT and healthy individuals compared to patients with allergic rhinitis. ${ }^{148} \mathrm{IL}-21$ controls effector $\mathrm{CD} 4^{+} \mathrm{T}$ cell responses and Tregs homeostasis. In a mice study, IL-21 directly promotes apoptosis of Tregs by interfering with the expression of Bcl-2 family genes and therefore indirectly sustains generation of inflammatory $\mathrm{T}$ effector cell responses. ${ }^{149}$

MicroRNA (miR) regulates protein expression post-transcriptionally through mRNA destabilization or translational silencing and implicates for adoptive cellular therapy. The study in allergic rhinitis children revealed miR 188a transfected into Tregs, which promoted IL-10 and TGF- $\beta$. The miR-155 also promoted Treg proliferation directly through suppressor of cytokine signaling 1 (SOCS1) and sirtuin1 (SIRT1) signaling pathway. ${ }^{150}$

\section{Conclusion}

In the last two decades, it has been discovered that various functional Treg cell subsets exist in the immune system. Dysregulated or irregular Treg cell function is one of the current hypotheses for the development and the immunopathology of allergic diseases. Further evidence has demonstrated that both FOXP $^{+}$Tregs and Tr 1 cells play a vital role in peripheral T-cell tolerance to allergens in healthy individuals. Tregs regulate allergic immune responses in type 2 immune cells through the suppressive mechanism and contribute to the control of allergic diseases in several pathways. AIT is an induction therapy and maintains allergen immune tolerance in patients with allergic diseases. In a successful AIT, significant increase in functional Tregs and a decrease in dysfunctional Tregs are associated with improvement in allergic symptoms. Curative therapeutic strategies specifically targeting Tregs are expected to develop in the future and may be promising as a treatment option in the management of allergic diseases. 


\section{References}

1. Boonpiyathad T, Sozener ZC, Satitsuksanoa P, Akdis CA. Immunologic mechanisms in asthma. Semin Immunol. 2019;46:101333.

2. Meng Y, Wang C, Zhang L. Recent developments and highlights in allergic rhinitis. Allergy. 2019;74:2320-8

3. Sugita K, Altunbulakli C, Morita H, Sugita A, Kubo T, Kimura R, et al. Human type 2 innate lymphoid cells disrupt skin keratinocyte tight junction barrier by IL-13. Allergy. 2019;74:2534-7.

4. Sugita K, Steer CA, Martinez-Gonzalez I, Altunbulakli C, Morita H, Castro-Giner F, et al. Type 2 innate lymphoid cells disrupt bronchial epithelial barrier integrity by targeting tight junctions through IL-13 in asthmatic patients. J Allergy Clin Immunol. 2018;141:300-10 e11.

5. Wawrzyniak P, Wawrzyniak M, Wanke K, Sokolowska M, Bendelja K, Ruckert B, et al. Regulation of bronchial epithelial barrier integrity by type 2 cytokines and histone deacetylases in asthmatic patients. J Allergy Clin Immunol. 2017;139:93-103.

6. Lv J, Yu Q, Lv J, Di C, Lin X, Su W, et al. Airway epithelial TSLP production of TLR2 drives type 2 immunity in allergic airway inflammation. Eur J Immunol. 2018;48:1838-50.

7. Li J, Zhang L, Chen X, Chen D, Hua X, Bian F, et al. Pollen/TLR4 Innate Immunity Signaling Initiates IL-33/ST2/Th2 Pathways in Allergic Inflammation. Sci Rep. 2016;6:36150.

8. van Zelm MC, McKenzie CI, Varese N, Rolland JM, O'Hehir RE. Recent developments and highlights in immune monitoring of allergen immunotherapy. Allergy. 2019;74:2342-54.

9. Sokolowska M, Boonpiyathad T, Escribese MM, Barber D. Allergen -specific immunotherapy: Power of adjuvants and novel predictive biomarkers. Allergy. 2019;74:2061-3

10. Palomares O, Yaman G, Azkur AK, Akkoc T, Akdis M, Akdis CA. Role of Treg in immune regulation of allergic diseases. Eur J Immunol. 2010;40:1232-40

11. Boonpiyathad T, Satitsuksanoa P, Akdis M, Akdis CA. Il-10 producing T and B cells in allergy. Semin Immunol. 2019;44:101326.

12. Globinska A, Boonpiyathad T, Satitsuksanoa P, Kleuskens M, van de Veen W, Sokolowska M, et al. Mechanisms of allergen-specific immunotherapy: Diverse mechanisms of immune tolerance to allergens. Ann Allergy Asthma Immunol. 2018;121:306-12.

13. Agache I, Lau S, Akdis CA, Smolinska S, Bonini M, Cavkaytar O, et al. EAACI Guidelines on Allergen Immunotherapy: House dust mite-driven allergic asthma. Allergy. 2019;74:855-73.

14. Wahn U, Bachert C, Heinrich J, Richter H, Zielen S. Real-world benefits of allergen immunotherapy for birch pollen-associated allergic rhinitis and asthma. Allergy. 2019;74:594-604

15. Reier-Nilsen T, Michelsen MM, Lodrup Carlsen KC, Carlsen KH, Mowinckel P, Nygaard UC, et al. Feasibility of desensitizing children highly allergic to peanut by high-dose oral immunotherapy. Allergy. 2019;74: 337-48.

16. Devillier P, Molimard M, Ansolabehere X, Bardoulat I, Coulombel $\mathrm{N}$, Maurel $\mathrm{F}$, et al. Immunotherapy with grass pollen tablets reduces medication dispensing for allergic rhinitis and asthma: A retrospective database study in France. Allergy. 2019;74:1317-26.

17. Huang Y, Wang C, Wang X, Zhang L, Lou H. Efficacy and safety of subcutaneous immunotherapy with house dust mite for allergic rhinitis: A Meta-analysis of Randomized Controlled Trials. Allergy. 2019;74:189-92.

18. Alviani C, Roberts G, Moyses H, Pearson S, Larsson M, Zolkipli Z, et al. Follow-up, 18 months off house dust mite immunotherapy, of a randomized controlled study on the primary prevention of atopy. Allergy. 2019;74:1406-8

19. Muraro A, Roberts G, Halken S, Agache I, Angier E, Fernandez-Rivas M, et al. EAACI guidelines on allergen immunotherapy: Executive statement. Allergy. 2018;73:739-43.

20. Boonpiyathad T, Meyer N, Moniuszko M, Sokolowska M, Eljaszewicz A, Wirz OF, et al. High-dose bee venom exposure induces similar tolerogenic B-cell responses in allergic patients and healthy beekeepers. Allergy. 2017; 72:407-15.

21. Pfaar O, Agache I, de Blay F, Bonini S, Chaker AM, Durham SR, et al. Perspectives in allergen immunotherapy: 2019 and beyond. Allergy. 2019; 74 Suppl 108:3-25.

22. Durham SR. The allergen specificity of allergen immunotherapy-doubt no more. Allergy. 2019;74:2054-6.

23. Boonpiyathad T, Sokolowska M, Morita H, Ruckert B, Kast JI, Wawrzyniak $\mathrm{M}$, et al. Der p 1-specific regulatory T-cell response during house dust mite allergen immunotherapy. Allergy. 2019;74:976-85.
24. Boonpiyathad T, van de Veen W, Wirz O, Sokolowska M, Ruckert B, Tan $\mathrm{G}$, et al. Role of Der p 1-specific B cells in immune tolerance during 2 years of house dust mite-specific immunotherapy. J Allergy Clin Immunol. 2019;143:1077-86 e10.

25. Soria I, Lopez-Relano J, Vinuela M, Tudela JI, Angelina A, Benito-Villalvilla C, et al. Oral myeloid cells uptake allergoids coupled to mannan driving Th1/Treg responses upon sublingual delivery in mice. Allergy. 2018;73: 875-84.

26. Yang LT, Shu Q, Luo XQ, Liu ZQ, Qiu SQ, Liu JQ, et al. Long-term effects: Galectin-1 and specific immunotherapy for allergic responses in the intestine. Allergy. 2018;73:106-14

27. Looman KIM, van Meel ER, Grosserichter-Wagener C, Vissers FJM, Klingenberg JH, de Jong NW, et al. Associations of Th2, Th17, Treg cells, and $\operatorname{IgA}(+)$ memory B cells with atopic disease in children: The Generation R Study. Allergy. 2020;75:178-87.

28. Bousquet J, Pfaar O, Togias A, Schunemann HJ, Ansotegui I, Papadopoulos NG, et al. 2019 ARIA Care pathways for allergen immunotherapy. Allergy. 2019;74:2087-102.

29. Hesse L, van Ieperen N, Habraken C, Petersen AH, Korn S, Smilda T, et al Subcutaneous immunotherapy with purified Der p1 and 2 suppresses type 2 immunity in a murine asthma model. Allergy. 2018;73:862-74.

30. Varona R, Ramos T, Escribese MM, Jimeno L, Galan A, Wurtzen PA, et al. Persistent regulatory T-cell response 2 years after 3 years of grass tablet SLIT: Links to reduced eosinophil counts, sIgE levels, and clinical benefit. Allergy. 2019;74:349-60.

31. Zhang H, Kong H, Zeng X, Guo L, Sun X, He S. Subsets of regulatory T cells and their roles in allergy. J Transl Med. 2014;12:125.

32. Chinen T, Kannan AK, Levine AG, Fan X, Klein U, Zheng Y, et al. An essential role for the IL-2 receptor in Treg cell function. Nat Immunol. 2016;17:1322-33.

33. Lee W, Lee GR. Transcriptional regulation and development of regulatory $\mathrm{T}$ cells. Exp Mol Med. 2018;50:e456.

34. Wu Y, Borde M, Heissmeyer V, Feuerer M, Lapan AD, Stroud JC, et al FOXP3 controls regulatory $T$ cell function through cooperation with NFAT. Cell. 2006;126:375-87.

35. Palomares O, Akdis M, Martin-Fontecha M, Akdis CA. Mechanisms of immune regulation in allergic diseases: the role of regulatory $\mathrm{T}$ and $\mathrm{B}$ cells. Immunol Rev. 2017;278:219-36.

36. Thornton AM, Lu J, Korty PE, Kim YC, Martens C, Sun PD, et al. Helios(+) and Helios(-) Treg subpopulations are phenotypically and functionally distinct and express dissimilar TCR repertoires. Eur J Immunol. 2019;49: 398-412.

37. Akimova T, Beier UH, Wang L, Levine MH, Hancock WW. Helios expression is a marker of $\mathrm{T}$ cell activation and proliferation. PLoS One 2011;6:e24226.

38. Takatori H, Kawashima H, Matsuki A, Meguro K, Tanaka S, Iwamoto T, et al. Helios Enhances Treg Cell Function in Cooperation With FoxP3. Arthritis Rheumatol. 2015;67:1491-502.

39. Wegrzyn AS, Jakiela B, Ruckert B, Jutel M, Akdis M, Sanak M, et al. T-cell regulation during viral and nonviral asthma exacerbations. The Journal of allergy and clinical immunology. 2015;136:194-7 e9.

40. Shin JU, Kim SH, Noh JY, Kim JH, Kim HR, Jeong KY, et al. Allergen -specific immunotherapy induces regulatory $\mathrm{T}$ cells in an atopic dermatitis mouse model. Allergy. 2018;73:1801-11.

41. Agache I. EAACI guidelines on allergen immunotherapy-Out with the old and in with the new. Allergy. 2018;73:737-8.

42. Radulovic S, Jacobson MR, Durham SR, Nouri-Aria KT. Grass pollen immunotherapy induces Foxp3-expressing $\mathrm{CD} 4{ }^{+} \mathrm{CD} 25^{+}$cells in the nasal mucosa. J Allergy Clin Immunol. 2008;121:1467-72, 72 e1.

43. Schmidl C, Delacher M, Huehn J, Feuerer M. Epigenetic mechanisms regulating T-cell responses. J Allergy Clin Immunol. 2018;142:728-43.

44. Morikawa H, Ohkura N, Vandenbon A, Itoh M, Nagao-Sato S, Kawaji $\mathrm{H}$, et al. Differential roles of epigenetic changes and Foxp3 expression in regulatory T cell-specific transcriptional regulation. Proc Natl Acad Sci U S A. 2014;111:5289-94.

45. Sun CM, Hall JA, Blank RB, Bouladoux N, Oukka M, Mora JR, et al. Small intestine lamina propria dendritic cells promote de novo generation of Foxp3 T reg cells via retinoic acid. J Exp Med. 2007;204:1775-85.

46. Soroosh P, Doherty TA, Duan W, Mehta AK, Choi H, Adams YF, et al Lung-resident tissue macrophages generate Foxp $3^{+}$regulatory $\mathrm{T}$ cells and promote airway tolerance. J Exp Med. 2013;210:775-88. 
47. Noval Rivas M, Chatila TA. Regulatory T cells in allergic diseases. J Allergy Clin Immunol. 2016;138:639-52.

48. Yadav M, Louvet C, Davini D, Gardner JM, Martinez-Llordella M, Bailey-Bucktrout S, et al. Neuropilin-1 distinguishes natural and inducible regulatory $\mathrm{T}$ cells among regulatory $\mathrm{T}$ cell subsets in vivo. J Exp Med. 2012;209:1713-22, S1-19.

49. Thornton AM, Korty PE, Tran DQ, Wohlfert EA, Murray PE, Belkaid Y, et al. Expression of Helios, an Ikaros transcription factor family member, differentiates thymic-derived from peripherally induced Foxp $^{+}$T regulatory cells. J Immunol. 2010;184:3433-41.

50. Zhou X, Bailey-Bucktrout SL, Jeker LT, Penaranda C, Martinez-Llordella M, Ashby M, et al. Instability of the transcription factor Foxp3 leads to the generation of pathogenic memory T cells in vivo. Nat Immunol. 2009;10: 1000-7.

51. Joetham A, Schedel M, O'Connor BP, Kim S, Takeda K, Abbott J, et al. Inducible and naturally occurring regulatory $\mathrm{T}$ cells enhance lung allergic responses through divergent transcriptional pathways. J Allergy Clin Immunol. 2017;139:1331-42.

52. Huang H, Ma Y, Dawicki W, Zhang X, Gordon JR. Comparison of induced versus natural regulatory $\mathrm{T}$ cells of the same TCR specificity for induction of tolerance to an environmental antigen. J Immunol. 2013;191:1136-43.

53. Moldenhauer LM, Schjenken JE, Hope CM, Green ES, Zhang B, Eldi $\mathrm{P}$, et al. Thymus-Derived Regulatory T Cells Exhibit Foxp3 Epigenetic Modification and Phenotype Attenuation after Mating in Mice. J Immunol. 2019;203:647-57.

54. Guan Q, Yang B, Warrington RJ, Mink S, Kalicinsky C, Becker AB, et al. Myeloid-derived suppressor cells: Roles and relations with Th2, Th17, and Treg cells in asthma. Allergy. 2019;74:2233-7.

55. Gogali F, Paterakis G, Rassidakis GZ, Kaltsas G, Liakou CI, Gousis P, et al. Phenotypical analysis of lymphocytes with suppressive and regulatory properties (Tregs) and NK cells in the papillary carcinoma of thyroid. J Clin Endocrinol Metab. 2012;97:1474-82.

56. Vocanson M, Rozieres A, Hennino A, Poyet G, Gaillard V, Renaudineau $\mathrm{S}$, et al. Inducible costimulator (ICOS) is a marker for highly suppressive antigen-specific $\mathrm{T}$ cells sharing features of $\mathrm{TH} 17 / \mathrm{TH} 1$ and regulatory $\mathrm{T}$ cells. J Allergy Clin Immunol. 2010;126:280-9, 9 e1-7.

57. Chen Q, Mo L, Cai X, Wei L, Xie Z, Li H, et al. ICOS signal facilitates Foxp3 transcription to favor suppressive function of regulatory $\mathrm{T}$ cells. Int J Med Sci. 2018;15:666-73

58. Zheng J, Chan PL, Liu Y, Qin G, Xiang Z, Lam KT, et al. ICOS regulates the generation and function of human $\mathrm{CD} 4^{+}$Treg in a CTLA- 4 dependent manner. PLoS One. 2013;8:e82203.

59. Rigas D, Lewis G, Aron JL, Wang B, Banie H, Sankaranarayanan I, et al. Type 2 innate lymphoid cell suppression by regulatory $\mathrm{T}$ cells attenuates airway hyperreactivity and requires inducible T-cell costimulator-inducible T-cell costimulator ligand interaction. J Allergy Clin Immunol. 2017;139:1468-77 e2.

60. Aron JL, Akbari O. Regulatory T cells and type 2 innate lymphoid cell -dependent asthma. Allergy. 2017;72:1148-55.

61. Hrusch CL, Stein MM, Gozdz J, Holbreich M, von Mutius E, Vercelli D, et al. T-cell phenotypes are associated with serum IgE levels in Amish and Hutterite children. J Allergy Clin Immunol. 2019;144:1391-401 e10.

62. Gagliani N, Magnani CF, Huber S, Gianolini ME, Pala M, Licona-Limon P, et al. Coexpression of CD49b and LAG-3 identifies human and mouse T regulatory type 1 cells. Nat Med. 2013;19:739-46.

63. Akdis CA, Akdis M. Mechanisms of immune tolerance to allergens: role of IL-10 and Tregs. J Clin Invest. 2014;124:4678-80.

64. Akdis CA, Blesken T, Akdis M, Wuthrich B, Blaser K. Role of interleukin 10 in specific immunotherapy. J Clin Invest. 1998;102:98-106.

65. van de Veen W, Akdis M. Role of IgG4 in IgE-mediated allergic responses. J Allergy Clin Immunol. 2016;138:1434-5

66. Bianchini R, Roth-Walter F, Ohradanova-Repic A, Flicker S, Hufnagl $\mathrm{K}$, Fischer $\mathrm{MB}$, et al. IgG4 drives M2a macrophages to a regulatory M2b-like phenotype: potential implication in immune tolerance. Allergy. 2019;74:483-94.

67. Akdis M, Verhagen J, Taylor A, Karamloo F, Karagiannidis C, Crameri R, et al. Immune responses in healthy and allergic individuals are characterized by a fine balance between allergen-specific $\mathrm{T}$ regulatory 1 and $\mathrm{T}$ helper 2 cells. J Exp Med. 2004;199:1567-75.

68. Pellerin L, Jenks JA, Chinthrajah S, Dominguez T, Block W, Zhou X, et al. Peanut-specific type 1 regulatory $T$ cells induced in vitro from allergic subjects are functionally impaired. J Allergy Clin Immunol. 2018;141: 202-13 e8.
69. Pacciani V, Gregori S, Chini L, Corrente S, Chianca M, Moschese V, et al. Induction of anergic allergen-specific suppressor $\mathrm{T}$ cells using tolerogenic dendritic cells derived from children with allergies to house dust mites. J Allergy Clin Immunol. 2010;125:727-36.

70. Mobs C, Slotosch C, Loffler H, Jakob T, Hertl M, Pfutzner W. Birch pollen immunotherapy leads to differential induction of regulatory $\mathrm{T}$ cells and delayed helper T cell immune deviation. J Immunol. 2010;184: 2194-203.

71. Gueguen C, Luce S, Lombardi V, Baron-Bodo V, Moingeon P, Mascarell L. IL-10 mRNA levels in whole blood cells correlate with house dust mite allergen immunotherapy efficacy. Allergy. 2019;74:2223-6.

72. Mailer RKW. Alternative Splicing of FOXP3-Virtue and Vice. Front Immunol. 2018;9:530.

73. Fenoglio D, Ferrera F, Fravega M, Balestra P, Battaglia F, Proietti M, et al. Advancements on phenotypic and functional characterization of non -antigen-specific $\mathrm{CD}^{+}{ }^{+} \mathrm{CD} 28^{-}$regulatory T cells. Hum Immunol. 2008;69: 745-50.

74. Siegmund K, Ruckert B, Ouaked N, Burgler S, Speiser A, Akdis CA, et al. Unique phenotype of human tonsillar and in vitro-induced $\mathrm{FOXP} 3^{+} \mathrm{CD}{ }^{+}$ T cells. J Immunol. 2009;182:2124-30.

75. Yu Y, Ma X, Gong R, Zhu J, Wei L, Yao J. Recent advances in CD8(+) regulatory T cell research. Oncol Lett. 2018;15:8187-94.

76. Eusebio M, Kuna P, Kraszula L, Kupczyk M, Pietruczuk M. The relative values of $\mathrm{CD}^{+} \mathrm{CD} 25^{+}$Foxp3brigh Treg cells correlate with selected lung function parameters in asthma. Int J Immunopathol Pharmacol. 2015; 28:218-26

77. Tsai YG, Yang KD, Niu DM, Chien JW, Lin CY. TLR2 agonists enhance $\mathrm{CD}^{+}{ }^{+} \mathrm{Foxp}^{+}$regulatory $\mathrm{T}$ cells and suppress Th2 immune responses during allergen immunotherapy. J Immunol. 2010;184:7229-37.

78. Tsai YG, Yang KD, Wen YS, Hung CH, Chien JW, Lin CY. Allergen-specific immunotherapy enhances CD8(+) CD25(+) CD137(+) regulatory T cells and decreases nasal nitric oxide. Pediatr Allergy Immunol. 2019;30:531-9.

79. Mercer F, Khaitan A, Kozhaya L, Aberg JA, Unutmaz D. Differentiation of IL-17-producing effector and regulatory human T cells from lineage -committed naive precursors. J Immunol. 2014;193:1047-54.

80. Jung MK, Kwak JE, Shin EC. IL-17A-Producing Foxp3(+) Regulatory T Cells and Human Diseases. Immune Netw. 2017;17:276-86.

81. Voo KS, Wang YH, Santori FR, Boggiano C, Wang YH, Arima K, et al. Identification of IL-17-producing $\mathrm{FOXP}^{+}$regulatory $\mathrm{T}$ cells in humans. Proc Natl Acad Sci U S A. 2009;106:4793-8.

82. Ueno A, Jijon H, Chan R, Ford K, Hirota C, Kaplan GG, et al. Increased prevalence of circulating novel IL-17 secreting Foxp3 expressing CD4 ${ }^{+} \mathrm{T}$ cells and defective suppressive function of circulating Foxp $3^{+}$regulatory cells support plasticity between Th17 and regulatory $\mathrm{T}$ cells in inflammatory bowel disease patients. Inflamm Bowel Dis. 2013;19:2522-34.

83. Cheng X, Lou W, Wang C, Zhang W, Han D, Zhang L. FOXP3-marked IL-17a-producing regulatory $\mathrm{T}$ cells are increased in patients with allergic rhinitis. Acta Otolaryngol. 2012;132:1311-7.

84. Albano GD, Di Sano C, Bonanno A, Riccobono L, Gagliardo R, Chanez $\mathrm{P}$, et al. Th17 immunity in children with allergic asthma and rhinitis: a pharmacological approach. PLoS One. 2013;8:e58892.

85. Zissler UM, Jakwerth CA, Guerth FM, Pechtold L, Aguilar-Pimentel JA, Dietz K, et al. Early IL-10 producing B-cells and coinciding Th/Tr17 shifts during three year grass-pollen AIT. EBioMedicine. 2018;36:475-88.

86. Daniel V, Wang H, Sadeghi M, Opelz G. Interferon-gamma producing regulatory $\mathrm{T}$ cells as a diagnostic and therapeutic tool in organ transplantation. Int Rev Immunol. 2014;33:195-211.

87. Feng T, Cao AT, Weaver CT, Elson CO, Cong Y. Interleukin- 12 converts Foxp $3^{+}$regulatory $\mathrm{T}$ cells to interferon-gamma-producing Foxp $3^{+} \mathrm{T}$ cells that inhibit colitis. Gastroenterology. 2011;140:2031-43.

88. Gangaplara A, Martens C, Dahlstrom E, Metidji A, Gokhale AS, Glass $\mathrm{DD}$, et al. Type I interferon signaling attenuates regulatory $\mathrm{T}$ cell function in viral infection and in the tumor microenvironment. PLoS Pathog. 2018;14:e1006985.

89. Daniel V, Trojan K, Adamek M, Opelz G. IFNgamma ${ }^{+}$Treg in-vivo and in-vitro represent both activated nTreg and peripherally induced aTreg and remain phenotypically stable in-vitro after removal of the stimulus. BMC Immunol. 2015;16:45.

90. Marques CR, Costa RS, Costa GNO, da Silva TM, Teixeira TO, de Andrade EMM, et al. Genetic and epigenetic studies of FOXP3 in asthma and allergy. Asthma Res Pract. 2015;1:10. 
91. Zhang L, Zhang Y, Desrosiers M, Wang C, Zhao Y, Han D. Genetic association study of FOXP3 polymorphisms in allergic rhinitis in a Chinese population. Hum Immunol. 2009;70:930-4.

92. Bottema RW, Kerkhof M, Reijmerink NE, Koppelman GH, Thijs C, Stelma FF, et al. X-chromosome Forkhead Box P3 polymorphisms associate with atopy in girls in three Dutch birth cohorts. Allergy. 2010;65:865-74.

93. Collier F, Ponsonby AL, O'Hely M, Tang MLK, Saffery R, Molloy J, et al. Naive regulatory $\mathrm{T}$ cells in infancy: Associations with perinatal factors and development of food allergy. Allergy. 2019;74:1760-8.

94. Tulic MK, Andrews D, Crook ML, Charles A, Tourigny MR, Moqbel R, et al. Changes in thymic regulatory T-cell maturation from birth to puberty: differences in atopic children. J Allergy Clin Immunol. 2012;129:199-206 e1-4.

95. Kinoshita T, Baatjes A, Smith SG, Dua B, Watson R, Kawayama T, et al. Natural regulatory $\mathrm{T}$ cells in isolated early responders compared with dual responders with allergic asthma. J Allergy Clin Immunol. 2014;133: 696-703.

96. Lin YL, Shieh CC, Wang JY. The functional insufficiency of human $\mathrm{CD} 4{ }^{+} \mathrm{CD} 25$ high T-regulatory cells in allergic asthma is subjected to TNF-alpha modulation. Allergy. 2008;63:67-74.

97. Thunberg S, Gafvelin G, Nord M, Gronneberg R, Grunewald J, Eklund A, et al. Allergen provocation increases TH2-cytokines and FOXP3 expression in the asthmatic lung. Allergy. 2010;65:311-8.

98. Liu X, Li S, Jin J, Zhu T, Xu K, Liu C, et al. Preventative tracheal administration of interleukin-27 attenuates allergic asthma by improving the lung Th1 microenvironment. J Cell Physiol. 2019;234:6642-53.

99. Nguyen QT, Jang E, Le HT, Kim S, Kim D, Dvorina N, et al. IL-27 targets Foxp $3^{+}$Tregs to mediate antiinflammatory functions during experimental allergic airway inflammation. JCI Insight. 2019;4:e123216.

100. Swamy RS, Reshamwala N, Hunter T, Vissamsetti S, Santos CB, Baroody $\mathrm{FM}$, et al. Epigenetic modifications and improved regulatory T-cell function in subjects undergoing dual sublingual immunotherapy. J Allergy Clin Immunol. 2012;130:215-24 e7.

101.Zhang Z, Zhou X. Foxp3 Instability Helps tTregs Distinguish Self and Non-self. Front Immunol. 2019;10:2226.

102.Xu K, Yang WY, Nanayakkara GK, Shao Y, Yang F, Hu W, et al. GATA3, HDAC6, and BCL6 Regulate FOXP3 ${ }^{+}$Treg Plasticity and Determine Treg Conversion into Either Novel Antigen-Presenting Cell-Like Treg or Th1-Treg. Front Immunol. 2018;9:45.

103. Chen T, Hou X, Ni Y, Du W, Han H, Yu Y, et al. The Imbalance of FOXP3/ GATA3 in Regulatory T Cells from the Peripheral Blood of Asthmatic Patients. J Immunol Res. 2018;2018:3096183.

104. Van Gool F, Nguyen MLT, Mumbach MR, Satpathy AT, Rosenthal WL, Giacometti S, et al. A Mutation in the Transcription Factor Foxp3 Drives T Helper 2 Effector Function in Regulatory T Cells. Immunity. 2019;50: 362-77 e6.

105. Ulges A, Klein M, Reuter S, Gerlitzki B, Hoffmann M, Grebe N, et al. Protein kinase CK2 enables regulatory T cells to suppress excessive TH2 responses in vivo. Nat Immunol. 2015;16:267-75.

106. Boonpiyathad T, Capova G, Duchna HW, Croxford AL, Farine H, Dreher A, et al. Impact of high-altitude therapy on type- 2 immune responses in asthma patients. Allergy. 2020;75:84-94.

107. Russkamp D, Aguilar-Pimentel A, Alessandrini F, Gailus-Durner V, Fuchs $\mathrm{H}$, Ohnmacht $\mathrm{C}$, et al. IL-4 receptor alpha blockade prevents sensitization and alters acute and long-lasting effects of allergen-specific immunotherapy of murine allergic asthma. Allergy. 2019;74:1549-60.

108. Dardalhon V, Awasthi A, Kwon H, Galileos G, Gao W, Sobel RA, et al. IL-4 inhibits TGF-beta-induced Foxp $3^{+} \mathrm{T}$ cells and, together with TGF-beta, generates IL- $9^{+}$IL- $10^{+}$Foxp3(-) effector T cells. Nat Immunol. 2008;9:1347-55.

109. Tu L, Chen J, Zhang H, Duan L. Interleukin-4 Inhibits Regulatory T Cell Differentiation through Regulating $\mathrm{CD}_{103^{+}}$Dendritic Cells. Front Immunol. 2017;8:214.

110. Yang WC, Hwang YS, Chen YY, Liu CL, Shen CN, Hong WH, et al. Interleukin-4 Supports the Suppressive Immune Responses Elicited by Regulatory T Cells. Front Immunol. 2017;8:1508.

111. Yang K, Blanco DB, Neale G, Vogel P, Avila J, Clish CB, et al. Homeostatic control of metabolic and functional fitness of Treg cells by LKB1 signalling. Nature. 2017;548:602-6.

112. Chen CC, Kobayashi T, Iijima K, Hsu FC, Kita H. IL-33 dysregulates regulatory $\mathrm{T}$ cells and impairs established immunologic tolerance in the lungs. J Allergy Clin Immunol. 2017;140:1351-63 e7.
113. Siede J, Frohlich A, Datsi A, Hegazy AN, Varga DV, Holecska V, et al. IL-33 Receptor-Expressing Regulatory T Cells Are Highly Activated, Th2 Biased and Suppress CD4 T Cell Proliferation through IL-10 and TGFbeta Release. PLoS One. 2016;11:e0161507.

114. Koh B, Ulrich BJ, Nelson AS, Panangipalli G, Kharwadkar R, Wu W, et al. Bcl6 and Blimp1 reciprocally regulate ST2(+) Treg-cell development in the context of allergic airway inflammation. J Allergy Clin Immunol. 2020;

115. Liu B, Salgado OC, Singh S, Hippen KL, Maynard JC, Burlingame AL, et al The lineage stability and suppressive program of regulatory $\mathrm{T}$ cells require protein O-GlcNAcylation. Nat Commun. 2019;10:354.

116. Stefanovic N, Flohr C, Irvine AD. The exposome in atopic dermatitis Allergy. 2020;75:63-74.

117. Hradetzky S, Werfel T, Rosner LM. Autoallergy in atopic dermatitis Allergo J Int. 2015;24:16-22.

118. Kalekar LA, Rosenblum MD. Regulatory $\mathrm{T}$ cells in inflammatory skin disease: from mice to humans. Int Immunol. 2019;31:457-63.

119. Guttman-Yassky E, Zhou L, Krueger JG. The skin as an immune organ: Tolerance versus effector responses and applications to food allergy and hypersensitivity reactions. J Allergy Clin Immunol. 2019;144:362-74.

120.Li Y, Xu W, Yao J, Cheng H, Sun X, Li L. Correlation of Blood FoxP3+ Regulatory T Cells and Disease Activity of Atopic Dermatitis. J Immunol Res. 2019;2019:1820182.

121. Malhotra N, Leyva-Castillo JM, Jadhav U, Barreiro O, Kam C, O'Neill $\mathrm{NK}$, et al. RORalpha-expressing $\mathrm{T}$ regulatory cells restrain allergic skin inflammation. Sci Immunol. 2018;3:

122. Chen Y, Inobe J, Marks R, Gonnella P, Kuchroo VK, Weiner HL. Peripheral deletion of antigen-reactive T cells in oral tolerance. Nature. 1995;376: 177-80.

123. Prince BT, Devonshire AL, Erickson KA, Bergerson J, Fuleihan D, Szychlinski C, et al. Regulatory T-cell populations in children are affected by age and food allergy diagnosis. J Allergy Clin Immunol. 2017;140: 1194-6 e16.

124. Perezabad L, Lopez-Abente J, Alonso-Lebrero E, Seoane E, Pion M, Correa-Rocha $\mathrm{R}$. The establishment of cow's milk protein allergy in infants is related with a deficit of regulatory T cells (Treg) and vitamin D. Pediatr Res. 2017;81:722-30.

125. Shreffler WG, Wanich N, Moloney M, Nowak-Wegrzyn A, Sampson HA Association of allergen-specific regulatory $\mathrm{T}$ cells with the onset of clinical tolerance to milk protein. J Allergy Clin Immunol. 2009;123:43-52 e7.

126. Palomares $\mathrm{O}$. The role of regulatory $\mathrm{T}$ cells in IgE-mediated food allergy. J Investig Allergol Clin Immunol. 2013;23:371-82; quiz 2 p preceding 82.

127. Hadis U, Wahl B, Schulz O, Hardtke-Wolenski M, Schippers A, Wagner $\mathrm{N}$, et al. Intestinal tolerance requires gut homing and expansion of FoxP3 ${ }^{+}$ regulatory T cells in the lamina propria. Immunity. 2011;34:237-46.

128. Palomares O, Ruckert B, Jartti T, Kucuksezer UC, Puhakka T, Gomez E et al. Induction and maintenance of allergen-specific FOXP3 ${ }^{+}$Treg cells in human tonsils as potential first-line organs of oral tolerance. J Allergy Clin Immunol. 2012;129:510-20, 20 e1-9.

129. Syed A, Garcia MA, Lyu SC, Bucayu R, Kohli A, Ishida S, et al. Peanut oral immunotherapy results in increased antigen-induced regulatory T-cell function and hypomethylation of forkhead box protein 3 (FOXP3). J Allergy Clin Immunol. 2014;133:500-10.

130. Lexmond WS, Goettel JA, Lyons JJ, Jacobse J, Deken MM, Lawrence MG et al. FOXP $3^{+}$Tregs require WASP to restrain Th2-mediated food allergy. J Clin Invest. 2016;126:4030-44

131. Ohnmacht C. Microbiota, regulatory T cell subsets, and allergic disorders. Allergo J Int. 2016;25:114-23.

132. Schuijs MJ, Willart MA, Vergote K, Gras D, Deswarte K, Ege MJ, et al. Farm dust and endotoxin protect against allergy through A20 induction in lung epithelial cells. Science. 2015;349:1106-10.

133. Geuking MB, Cahenzli J, Lawson MA, Ng DC, Slack E, Hapfelmeier S, et al. Intestinal bacterial colonization induces mutualistic regulatory $\mathrm{T}$ cell responses. Immunity. 2011;34:794-806.

134. Atarashi K, Tanoue T, Shima T, Imaoka A, Kuwahara T, Momose Y, et al Induction of colonic regulatory $\mathrm{T}$ cells by indigenous Clostridium species. Science. 2011;331:337-41.

135. Round JL, Mazmanian SK. Inducible Foxp3 $3^{+}$regulatory T-cell development by a commensal bacterium of the intestinal microbiota. Proc Natl Acad Sci U S A. 2010;107:12204-9.

136. Arpaia N, Campbell C, Fan X, Dikiy S, van der Veeken J, deRoos P, et al. Metabolites produced by commensal bacteria promote peripheral regulatory T-cell generation. Nature. 2013;504:451-5. 
137. Vonk MM, Blokhuis BRJ, Diks MAP, Wagenaar L, Smit JJ, Pieters RHH, et al. Butyrate Enhances Desensitization Induced by Oral Immunotherapy in Cow's Milk Allergic Mice. Mediators Inflamm. 2019;2019:9062537.

138. Ruohtula T, de Goffau MC, Nieminen JK, Honkanen J, Siljander H, Hamalainen AM, et al. Maturation of Gut Microbiota and Circulating Regulatory T Cells and Development of IgE Sensitization in Early Life. Front Immunol. 2019;10:2494.

139. Du X, Wang L, Wu S, Yuan L, Tang S, Xiang Y, et al. Efficacy of probiotic supplementary therapy for asthma, allergic rhinitis, and wheeze: a meta-analysis of randomized controlled trials. Allergy Asthma Proc. 2019; 40:250-60.

140. Kwon HK, Lee CG, So JS, Chae CS, Hwang JS, Sahoo A, et al. Generation of regulatory dendritic cells and $\mathrm{CD} 4^{+} \mathrm{Foxp}^{+} \mathrm{T}$ cells by probiotics administration suppresses immune disorders. Proc Natl Acad Sci U S A. 2010;107:2159-64.

141. Konieczna P, Groeger D, Ziegler M, Frei R, Ferstl R, Shanahan F, et al. Bifidobacterium infantis 35624 administration induces Foxp3 $\mathrm{T}$ regulatory cells in human peripheral blood: potential role for myeloid and plasmacytoid dendritic cells. Gut. 2012;61:354-66.

142. Fassio F, Guagnini F. House dust mite-related respiratory allergies and probiotics: a narrative review. Clin Mol Allergy. 2018;16:15.

143. Jerzynska J, Stelmach W, Balcerak J, Woicka-Kolejwa K, Rychlik B, Blauz A, et al. Effect of Lactobacillus rhamnosus GG and vitamin D supplementation on the immunologic effectiveness of grass-specific sublingual immunotherapy in children with allergy. Allergy Asthma Proc. 2016;37:324-34.
144. Smaldini PL, Trejo F, Cohen JL, Piaggio E, Docena GH. Systemic IL-2/anti-IL-2Ab complex combined with sublingual immunotherapy suppresses experimental food allergy in mice through induction of mucosal regulatory T cells. Allergy. 2018;73:885-95.

145. Johnson-Weaver BT, Sempowski GD, Staats HF. Nasal peanut+ CpG immunotherapy enhances peanut-specific IFN-gamma in Th2 cells and IL-10 in non-Th2 cells in mice. Allergy. 2019;74:2220-3.

146. Burzyn D, Kuswanto W, Kolodin D, Shadrach JL, Cerletti M, Jang Y, et al. A special population of regulatory $\mathrm{T}$ cells potentiates muscle repair. Cell. 2013;155:1282-95.

147. Abdeladhim M, Zhang AH, Kropp LE, Lindrose AR, Venkatesha SH, Mitre $\mathrm{E}$, et al. Engineered ovalbumin-expressing regulatory $\mathrm{T}$ cells protect against anaphylaxis in ovalbumin-sensitized mice. Clin Immunol. 2019;207:49-54.

148. Shamji MH, Layhadi JA, Achkova D, Kouser L, Perera-Webb A, Couto -Francisco NC, et al. Role of IL-35 in sublingual allergen immunotherapy. J Allergy Clin Immunol. 2019;143:1131-42 e4.

149. Tortola L, Pawelski H, Sonar SS, Ampenberger F, Kurrer M, Kopf M. IL-21 promotes allergic airway inflammation by driving apoptosis of FoxP3(+) regulatory T cells. J Allergy Clin Immunol. 2019;143:2178-89 e5.

150.Zeng Q, Liu W, Luo R, Lu G. MicroRNA-181a and microRNA-155 are involved in the regulation of the differentiation and function of regulatory $\mathrm{T}$ cells in allergic rhinitis children. Pediatr Allergy Immunol. 2019;30: $434-42$. 